Ann. Biol. anim. Bioch. Biophys., 1978, 18 (2 B), 547-553.

\title{
Testosterone gradient across the tubular wall
}

\author{
by F. H. COMHAIRE, A. VERMEULEN \\ Section of Endocrinology of the Department of Internal Medicine, \\ State University, Akademisch Ziekenhuis, De Pintelaan, 135 \\ B 9000 Ghent, Belgium.
}

Summary. Testosterone concentration was measured in interstitial fluid and freeflow seminiferous tubular fluid obtained by micropuncture in anaesthesized rats. In 24 intact adult rats the mean testosterone concentration in tubular fluid was $95.3 \pm 9.5 \mathrm{ng} / \mathrm{ml}$ (SEM) ; that in interstitial fluid was $125.1 \pm 18.2 \mathrm{ng} / \mathrm{ml}$.

Whenever interstitial fluid concentration was less than $50 \mathrm{ng} / \mathrm{ml}$, tubular fluid concentration exceeded interstitial fluid concentration. In cases with inferstitial fluid concentration exceeding $50 \mathrm{ng} / \mathrm{ml}$, tubular fluid concentration was significantly lower than interstitial fluid concentration ( $p .<0.01$ ).

Treatment of intact adult rats with $\mathrm{C} 21$ steroids, precursors in the testosterone biosynthesis, such as $17 \mathrm{OH}$ Pregnenolone and DHEA sulfate, resulted in a significant increase of the testosterone concentration in both interstitial and tubular fluid with a disppearance of the gradient between the two. After hypophysectomy, interstitial and tubular fluid testosterone concentrations presented a rapid and parallel decrease ; treatment of hypophysectomized rats with $\mathrm{C} 21$ steroids did not result in normalisation of the testosterone concentration in either fluid. Taking into account the presumed role of androgen-binding protein in the transport of steroids, no arguments can be found in favour of testosterone biosynthesis by the tubular wall in vivo.

\section{Introduction.}

Many studies have been published concerning the in vitro conversion of testosterone and its precursors by isolated seminiferous tubules and interstitial tissue (Dufau ef al., 1971 ; Parvinen and Niemi, 1971 ; Cooke et al., 1972 ; Rivarola and Podesta, 1972; Folman ef al., 1973).

The aim of our investigations is to study the possible role of the seminiferous fubular wall in the transport and the biosynthesis of some sex steroids in vivo. As part of this study, we have determined testosterone concentration in the fluids obtained by micropuncture at the outside and the inside of the seminiferous tubular wall.

\section{Methods.}

Ninety-day old Wistar or CD strain (Charles River Breeding Laboratories, France) adult rats weighing $250 \mathrm{~g}$ were anaesthesized with ether and the testes exposed through scrotal incision. The testicular capsule was incised and a microcapillary 
was inserted between the protruding tubules. Cell-free interstitial fluid (IF) was obtained and pooled in a buffer solution. Then the protruding tubules were subjected to micropuncture (Tuck et al., 1970) and the fluid from 4 to 10 tubules of the same testicle was pooled, following the experimental procedure previously described(Comhaire and Vermeulen, 1976). Testosterone measurement by RIA (Vermeulen, 1973) was carried out on the complete samples. The limit of detection of the method is $20 \mathrm{pg}$ per sample, which corresponds to a testosterone concentration of $20 \mathrm{ng} / \mathrm{ml}$ for a sample volume of $1 \mu \mathrm{l}$, and to $40 \mathrm{ng} / \mathrm{ml}$ for a sample volume of $0.5 \mu \mathrm{l}$.

No correction was made for the cellular content of the tubular fluid ; this did not induce a larger error than the spermatocrit (Tuck ef al., 1970) which does not take into account the considerable androgen absorption by the spermatozoa.

The precision of the method as applied to a sample volume of $1 \mu \mathrm{l}$ was estimated by duplicate determinations and yielded a coefficient of variation of 10 p. 100 at a concentration of $100 \mathrm{ng} / \mathrm{ml}$.

\section{Results.}

Intact rats.

Basal values. - Interstitial and seminiferous tubular fluids (STF) were obtained in 24 intact rats. The testosterone concentration in STF varied between 42 and $227 \mathrm{ng} /$ $\mathrm{ml}$, with a mean of $95.2 \pm 9.5 \mathrm{ng} / \mathrm{ml}(\mathrm{SEM})$. The testosterone concentration in I.F. varied between 24 and $388 \mathrm{ng} / \mathrm{ml}$, with a mean of $125.1 \pm 18.2 \mathrm{ng} / \mathrm{ml}$ (fig. 1).

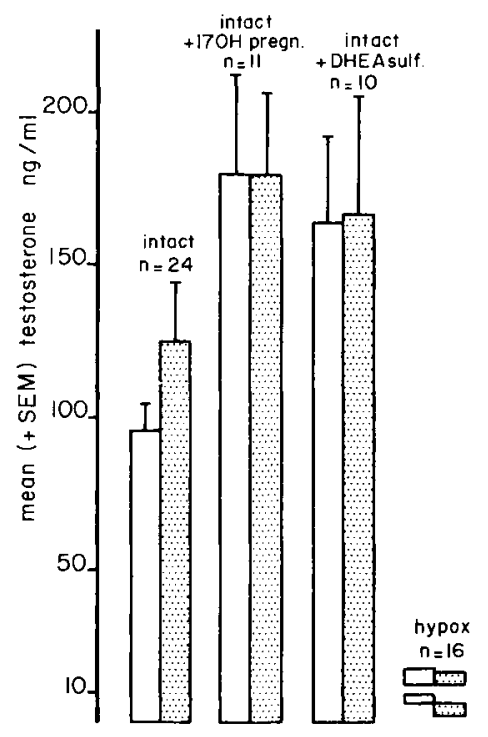

FIG. 1. - Testosterone concentration (mean + SEM; $\mathrm{ng} / \mathrm{ml}$ ) in seminiferous tubular fluid (STF) and interstitial fluid (IF) in rats in vivo. Among the hypophysectomized rats (Hypox) the superior blocks represent the distribution of fluid concentrations 3 days after hypophysectomy $(n=6)$; the inferior blocks correspond to the values obtained after 5 days or more $(n=10)$ (White : STF ; grey : IF). 
There was a strong correlation $(r=0.75 ; p<0.001)$ between the logarithm of the STF and IF testosterone concentrations; however, whenever the IF testosterone concentration was less than or equal to $50 \mathrm{ng} / \mathrm{ml}$, the STF concentration exceeded the IF concentration (fig. 2a). On the contrary, whenever IF concentration exceeded $50 \mathrm{ng} /$ $\mathrm{ml}$, STF concentration was significantly lower than IF concentration (Wilcoxon's test for paired observations : $\mathrm{p}<0.01$ ).

C21 precursor steroid treatment. - Daily subcutaneous injections of $2 \mathrm{mg}$ of 17 OH Pregnenolone during 14 to 21 days in 11 intact rats, resulted in a significantly higher value for both IF and STF testosterone concentrations (Wilcoxon's rank sum test : $p<0.05 ;$ fig. 1 ), with mean concentration for the former : $179.7 \pm 27.3 \mathrm{ng} / \mathrm{ml}$, for the latter : $180.1 \pm 31.7 \mathrm{ng} / \mathrm{ml}$. Despite the fact that all values for IF exceeded $50 \mathrm{ng} / \mathrm{ml}$ (fig. $2 b$ ), there was no statistically significant difference between IF and STF concentrations (Wilcoxon's test for paired observations).

After treatment of intact rats with $2 \mathrm{mg} /$ day of dehydroepiandrosterone sulfate, STF increased significantly (Wilcoxon's rank sum test : $p<0.05$ ) ; IF presented an insignificant increase. The mean testosterone concentration in STF equalled $163.6 \pm$ $28.6 \mathrm{ng} / \mathrm{ml}(\mathrm{n}=10)$; mean IF concentration was $166.2 \pm 39.6 \mathrm{ng} / \mathrm{ml}(\mathrm{n}=10)$. Again IF and STF concentrations did not differ significantly (fig. $2 c$ ).
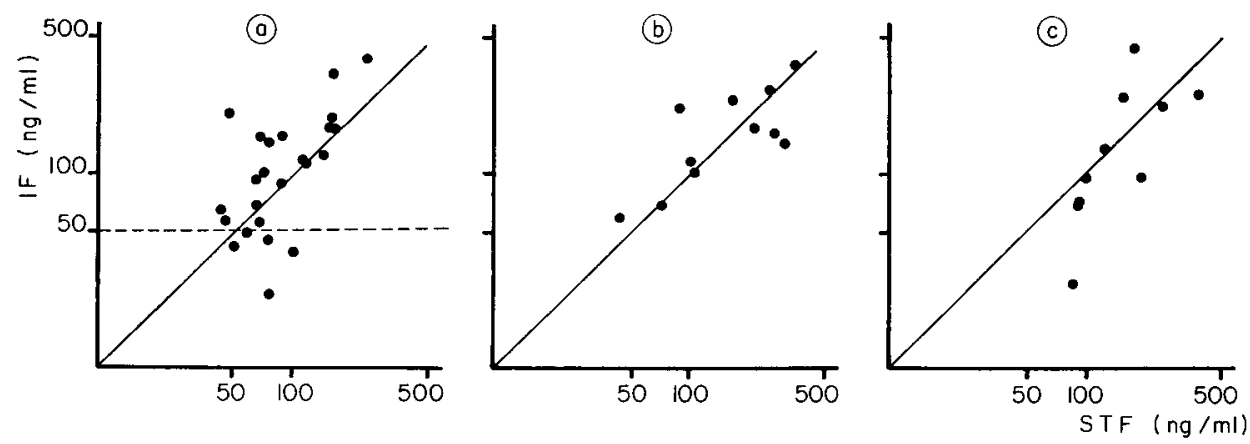

FIG. 2a. - Testosterone concentration (ng/ml) in interstitial fluid (IF) and seminiferous tubular fluid (STF) in intact adult rats. The points situated under the bisectrice have a STF concentration higher than that in IF, and vice versa for the points above the bisectrice. Note logarythmic scale.

FIG. 2b. - Testosterone concentration $(\mathrm{ng} / \mathrm{ml})$ in interstitial fluid (IF) and seminiferous fubular fluid (STF) in intoct adult rats treated with $17 \mathrm{OH}$ pregnenolone ( $2 \mathrm{mg} /$ day ; s. c.) during 21 days.

FIG. 2c. - Testosterone concentration (ng/ml) in interstitial fluid (IF) and seminiferous tubular fluid (STF) in intact adult rats treated with dehydroepiandrosterone sulfate $(2 \mathrm{mg} / \mathrm{day}, \mathrm{s}$. c.) during 21 days.

Hypophysectomized rats.

Basal values. - Three days after hypophysectomy the testosterone concentrations in both IF and STF were low but still detectable (between 10 and $20 \mathrm{ng} / \mathrm{ml}$ ). Five days or more after hypophysectomy all values for both fluids were below $10 \mathrm{ng} / \mathrm{ml}$ (fig. 1).

C21 precursor steroid treatment. - From the third day after hypophysectomy five hypophysectomized rats were treated with $17 \mathrm{OH}$ pregnenolone, $2 \mathrm{mg}$ per day, during 21 days. The testosterone concentrations in STF and IF were very low : STF 
concentration was below the limit of detection in 7 out of 10 testicles, IF concentration was undetectable in 4 out of 10 testicles. In the remaining cases testosterone concentration did not differ between the two fluids.

In 5 hypophysectomized adult rats, dehydroepiandrosterone sulfate was injected at a dose of $2 \mathrm{mg}$ per day for 21 days. In all 10 testicles the testosterone concentrations for both STF and IF were below the limit of detection.

\section{Discussion.}

The testosterone concentration is more elevated in IF than in testicular lymph and in spermatic venous plasma (Lindner, 1963). On the other hand, the concentration in IF observed in this study is lower than that reported by several authors for interstitial tissue (Cooke et al., 1972 ; Ruokonen et al., 1973 ; Podesta and Rivarola, 1974 ; De Jong ef al., 1974). This suggests the existence of a pool of testosterone within the Leydig cells.

Seminiferous tubular fluid testosterone concentration on the contrary seems to be higher than the concentration found by several authors (Cooke ef al., 1972 ; De Jong et al., 1974 ; Podesta and Rivarola, 1974) in the dissected seminiferous tubules. This finding suggests that either testosterone concentration in the tubular cells is relatively low, or that tubular cells lose part of their testosterone content during wet dissection (Rommerts et al., 1973).

The testosterone concentration in STF is clearly higher than the concentration in rete festis fluid reported by Cooper and Waites (1974), Harris and Bartke (1974) and ourselves (Comhaire and Vermeulen, 1976). In intact adult rats IF concentration is, as a rule, higher than the concentration in STF. This could be expected since the testosterone secretion occurs in the interstitial compartment. Only when IF concentration was less than $50 \mathrm{ng} / \mathrm{ml}$, did we find the STF concentration to exceed IF concentration. This however does not prove that testosterone biosynthesis has taken place in the fubular wall. Indeed, androgen-binding protein is present in the fubular fluid, and not in interstitial fluid (Hansson ef al., 1973). Its binding capacity in tubular fluid can be calculated to be about $50 \mathrm{ng}$ testosterone per $\mathrm{ml}$ in intact rats (Comhaire and Vermeulen, 1976). Unbound testosterone probably can diffuse freely from the interstitium into the seminiferous tubules. In the tubules, binding to androgen-binding protein occurs, resulting in a decrease of the free testosterone fraction. Due to the created free testosterone gradient, more testosterone will enter the seminiferous tubules, and as a result, the total testosterone concentration in STF will exceed that in IF.

This phenomenon will occur particularly whenever Leydig cell secretion is at rest (Cooper and Waites, 1974) and IF testosterone concentration is less than the binding capacity of intratubular androgen-binding protein.

Treatment of intact rats with C21 steroids, precursors in the testosterone biosynthesis, resulted in an increased testosterone concentration in both STF and IF. The gradient between the two fluids disappeared although IF testosterone concentration generally exceeded $50 \mathrm{ng} / \mathrm{ml}$. Since, however, testosterone concentration was increased in both IF and STF, it was impossible to decide whether or not testosterone biosynthesis by the seminiferous tubular cells had taken place. 
After hypophysectomy, IF and STF testosterone concentrations presented a rapid and parallel decrease to values below the limit of detection, and the injection of C21 precursors into hypophysectomized rats did not result in a measurable concentration of testosterone in either fluid. At first sight, our data contrast with the results reported by Harris and Bartke (1974). In hypophysectomized, C21 steroid-treated rats, those authors found the testosterone concentration in rete testis fluid to be similar to that in intact rats. However, testicular venous plasma testosterone concentration was lower than normal, though higher than in untreated hypophysectomized controls. From these data Harris and Bartke (1974) suggest that most of the C21 steroid conversion to testosterone must have occurred in the seminiferous tubules.

Since in our hypophysectomized, C21 steroid-treated rats, STF testosterone concentration is much lower than in intact rats, there seems to be a contradiction between the data on rete testis fluid and spermatic venous plasma on the one hand, and the results obtained in STF and IF on the other hand. This contradiction could be due to two factors :

1. Measurement of low concentrations for testosterone in small volumes of fluid is subject to relatively important errors, and no differences can be traced below the limit of detection. Due to a reduction of the tubular diameter, which itself correlates with the highly significant reduction in testicular weight observed in the studies of Harris and Bartke (1974), the volume of STF obtained in hypophysectomized rats, whether treated or not, is not more than $0.5 \mu \mathrm{l}$; hence the limit of detection is $40 \mathrm{ng} / \mathrm{ml}$ (20 pg/sample). As in intact rats mean STF concentration was $95.3 \pm 9.5 \mathrm{ng} / \mathrm{ml}$, it is evident nevertheless that the STF concentrations of festosterone, observed in hypophysectomized rats, are clearly lower than those observed in intact rats.

2. Whereas the origin of rete testis fluid in intact rats is relatively well known (Setchell et al., 1978), little is known about the fluid dynamics in hypophysectomized rats. The volume of rete testis fluid which can be obtained in hypophysectomized, C21 steroid-treated rats, is not more than $1 / 3$ of the volume obtained in intact rats. It is quite possible that the proportional composition of rete testis fluid in hypophysectomized animals is different and does not correlate with the composition of STF.

Although more work is clearly needed to elucidate these problems, our data do not introduce new arguments to sustain the hypothesis of testosterone biosynthesis by the seminiferous tubular wall in vivo.

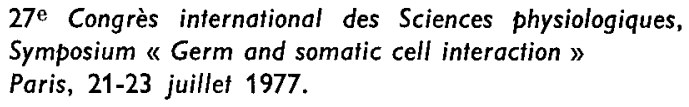

Acknowledgements. - The authors express their gratitude to Miss L. Vermeulen for technical assistance and to Miss L. Verdonck for the testosterone deferminations.

Résumé. La concentration de la testostérone a été déterminée dans le liquide interstitiel et dans le liquide intratubulaire obtenu par microponction chez des rats anesthésiés. Chez 24 rats adultes la concentration moyenne de la testostérone dans le liquide tubulaire était de $95,3 \pm 9,5 \mathrm{ng} / \mathrm{ml}$ (SEM), la moyenne dans le liquide interstitiel étant de $125,1 \pm 18,2 \mathrm{ng} / \mathrm{ml}$. Chaque fois que le taux de la testostérone dans le liquide interstitiel 
était inférieur à $50 \mathrm{ng} / \mathrm{ml}$, la concentration du liquide tubulaire dépassait celui du liquide interstitiel. Par contre, lorsque la concentration dans le liquide interstitiel dépassait $50 \mathrm{ng} / \mathrm{ml}$, celle dans le liquide tubulaire était significativement inférieure à celle dans le liquide interstitiel $(p .<0,01)$.

Le traitement de rats intacts par des stéroides $\mathrm{C} 21$, précurseurs dans la biosynthèse de la testostérone, tels que la $17 \mathrm{OH}$ pregnénolone ou la sulfate de DHEA, entraînait une augmentation de la concentration de la testostérone aussi bien dans le liquide tubulaire que dans le liquide interstitiel, le gradient entre ces deux liquides disparaissant, malgré le fait que la concentration de la testostérone dans le liquide interstitiel dépassait $50 \mathrm{ng} / \mathrm{ml}$ dans la majorité des cas. Après hypophysectomie, une diminution rapide ef parallèle de la concentration de la testostérone dans le liquide interstitiel et le liquide tubulaire a été observée.

Chez des rats hypophysectomisés il n'était pas possible de normaliser par un traitement aux stéroïdes C21 la concentration en testostérone dans les liquides étudiés.

Ces résultats sont discutés en relation avec le rôle présumé de la protéine liante d'androgènes $(A B P)$ dans le transport de la testostérone. Il est conclu à une absence d'arguments pouvant soutenir l'hypothèse d'une biosynthèse de testostérone par la paroi tubulaire chez le rat in vivo.

\section{References}

COMHAIRE F. H., VERMEULEN A., 1976. Testosterone concentration in the fluids of seminiferous tubules, the interstitium and the rete testis of the rat. J. Endocr., 70, 229-255.

COOKE B. A., DE JONG F. H., VAN DER MOLEN H. J., ROMMERTS F. F. G., 1972. Endogenous testosterone concentrations in rat testis interstitial tissue and seminiferous tubules during in vitro incubation. Nat. New Biol., 237, 255-256.

COOPER T. G., WAITES G. M. H., 1974. Testosterone in rete testis fluid and blood of rams and rats. J. Endocr., 62, 619-629.

DE JONG F. H., HEY A. H., VAN DER MOLEN H. J., 1974. Oestradiol-17 $\beta$ and testosterone in rat testis tissue : effect of gonadotrophins, localization and production in vitro. J. Endocr., 60, 409-419.

DUFAU M. L., DE KRETSER D. M., HUDSON B., 1971. Steroid metabolism by isolated rat seminiferous tubules in tissue culture. Endocrinol., 88, 825-832.

FOLMAN Y., AHMAD N., SOWELL J. C., EIK-NES K. B., 1973. Formation in vitro of $5 \alpha$-dihydrotestosterone and other $5 \alpha$-reduced metabolites of ${ }^{3} \mathrm{H}$-testosterone by the seminiferous tubules and interstitial tissue from immature and mature rat testis. Endocrinol., 92, 41-47.

HANSSON V., REUSCH E., TRYGSTAD O., TOGERSEN O., RITZEN E. M., FRENCH F. S., 1973. FSH stimulation of testicular androgen binding protein. Nat. New Biol., 246, 56-58.

HARRIS M. E., BARTKE A., 1974. Concentration of testosterone in rete testis fluid of the rat. Endocrinol., 95, 701-706.

LINDNER H. R., 1963.Partition of androgen between the lymph and venous blood of the testis in the ram. J. Endocr., 25, 483.

PARVINEN M., NIEMI M., 1971.Distribution and conversion of exogenous cholesterol and sex steroids in the seminiferous tubules and interstitial tissue of the rat testis. Steroidol., 2, 129-137.

PODESTA E. J., RIVAROLA M. A., 1974. Concentration of androgens in whole testis, seminiferous tubules and interstitial tissue of rats at different stages of development. Endocrinol., 95, 455-461.

RIVAROLA M. A., PODESTA E. J., 1972. Metabolism of testosterone ${ }^{14} \mathrm{C}$ by seminiferous tubules in mature rats : formation of $5 \alpha$-androstane- $3 \alpha, 17 \beta$-diol-14 C. Endocrinol., 90, 618-623.

ROMMERTS F. F. G., VAN DOORN L. G., GALJAARD H., COOKE B. A., VAN DER MOLEN H. J., 1973. Dissection of wet tissue and freeze-dried sections in the investigation of seminiferous tubules and interstitial tissue from rat testis. J. Hisfochem. Cytochem., 21, 572-579.

RUOKONEN A., VIHKO R., NIEMI M., 1973. Steroid metabolism in testis tissue. Concentrations of testosterone, pregnenolone and $5 \alpha$-androst-16-en-3 $\beta$-ol in normal and cryptorchid rat testis, and in isolated interstitial and tubular tissue. FEBS Letters, 31, 321-323. 
SETCHELL B. P., DAVIES R. V., HINTON B. T., MAIN S. J., PILSWORTH L. M., WAITES G. M. H., 1978. The movement of fluid in the seminiferous fubules and rete testis. Ann. Biol. anim., Bioch., Biophys., 18, 623-632.

TUCK R. R., SETCHELL B. P., WAITES G. M. H., 1970. The composition of fluid collected by micropuncture and catheterization from the seminiferous tubules and rete testis of rats. Pflüg. Arch. ges. Physiol., 318, 225-243.

VERMEULEN A., 1973. Determination of androgens in plasma, 91-103. In SERIO T., MARTINI L. E., The endocrine function of human testis, Acad. Press, New York, London. 